Katarzyna Kurzyca

Uniwersytet Śląki w Katowicach
Kiedy myślimy Rodzina..., red. M. Duda,

K. Kutek-Sładek, Kraków 2016, s. 35-46

(Praca Socjalna w Teorii i Działaniu, 2).

\title{
Produkt RODZINA - czy trzeba ją dziś reklamować?
}

Product: FAMILY - do we have to advertise it today?

\begin{abstract}
In this case the question appears, whether every product needs to be promoted. Aren't the conservative values overlooked in the modern advertising battle? Where's the family's place in the world immersed in the marketing? While searching for the answer to the questions mentioned above it is required to explore the following subjects: family's identification, characteristics, promotion's causes, objectives and forms. This
\end{abstract}

analysis of the family situation shows that its value is still perceived but it requires a kind of awakening, getting out of the shadow. Obviously, the involvement of representatives of all disciplines is invaluable so that the family's voice could reach everyone.

Keywords: family, advertisement, family functions, family promotion

Żyjemy w świecie, w którym znaczenie reklamy jest niezwykle duże i każdego dnia wzrasta $^{1}$. Opinie, poglądy, jak również działania ludzi, szczególnie młodych, są efektem m.in. oddziałujących na nich przekazów medialnych. Na przestrzeni lat reklama ewoluowała, nie dotyczy już tylko promocji produktów ${ }^{2}$. Coraz powszechniej działania przeróżnych instytucji nastawione są na

1 Etyka w reklamie, http://iaa.org.pl/o-reklamie/kodeksy/etyka-w-reklamie.html (29.05.2015).

2 A. Liwak, Reklama - jak to było od poczatku, http://obserwator.come.uw.edu.pl/ Reklama-historia_-_Agnieszka_Liwak-popr.pdf (29.05.2015). 
przekazywanie odbiorcom określonych wzorców zachowań, propagowanie wybranych ideologii, jak również kształtowanie hierarchii wartości.

Wobec takiego stanu rzeczy nasuwa się pytanie, czy każdy produkt, każda ideologia, każda wartość wymaga dziś promocji i ma do niej prawo. Czy istnieją takie produkty, które z uwagi na swoją powszechność powinny być pozostawione same sobie i w sposób naturalny być przyjmowane lub odrzucane przez społeczeństwo? Czy można wartości i postawy poddać takiej samej reklamowej obróbce jak produkty typu pasta do zębów czy masło?

Jedną ze wspomnianych powyżej wartości - uznawaną od wieków, a więc wydawać by się mogło, że powszechną i ugruntowaną - jest rodzina. Stąd też postawione w tytule niniejszego opracowania pytanie, czy rodzinę trzeba dziś reklamować.

Decyzja dotycząca procesu marketingowego danego produktu zapada w toku wieloetapowej analizy. Realizacja działań reklamowych zależy przede wszystkim od rodzaju promowanego produktu ${ }^{3}$ (dlatego też ważna jest początkowa diagnoza jego sytuacji na rynku). Niezwykle istotne jest też określenie celu reklamy ${ }^{4}$ (co wiąże się z wcześniejszym jasnym określeniem charakteru produktu, a także z określeniem grupy docelowej). Po ustaleniu powyższych danych następuje dobór odpowiedniej formy promocji, czyli takiej, która będzie najbardziej korzystna z uwagi na obrany wcześniej cel. W zależności od momentu wprowadzania reklamy wyróżniamy cztery etapy reklamy odpowiadające etapom „życia” produktu: uświadomienie istnienia produktu, budowanie świadomości (umiejętnego odróżniania promowanego produktu od innych), podkreślanie różnic i korzyści, a także przypominanie o produkcie ${ }^{5}$.

W oparciu o powyższe informacje, dotyczące planowania działań marketingowych, poniżej przeprowadzono analizę produktu: rodzina. Celem tego zabiegu jest nie tylko sprawdzenie, czy możliwe jest poddanie tej wartości prawom produktu, ale przede wszystkim udzielenie odpowiedzi na pytanie, czy rodzina wymaga dziś promocji, a w przypadku odpowiedzi twierdzącej - jaka forma reklamy rodziny powinna być w tej sytuacji stosowana.

\section{Rodzina - stan faktyczny i wizerunek kreowany w świecie}

Poszukiwanie odpowiedzi na pytanie o konieczność promocji danego produktu poprzedzone jest diagnozą aktualnej sytuacji na rynku. Podobna identyfi-

\footnotetext{
J. Tkaczyk, Przepis na reklame, „Pro-Kreacja” nr 3 (2006), s. 57.

Tamże.

5 Tamże.
} 
kacja musi więc także stanowić podstawę rozważań na temat reklamy rodziny. Jaki jest zatem dzisiejszy wizerunek rodziny?

Na początku należy przyjrzeć się postrzeganiu rodziny w kontekście znaczenia przypisywanego temu słowu. Konieczne jest tutaj podkreślenie faktu, iż pojęcie rodziny poddawane jest współcześnie ciągłemu redefiniowaniu. Próbuje się je rozszerzyć na różne formy wspólnego pożycia ludzi. Mianem rodziny coraz częściej określa się to, co sami zainteresowani uznają za swoją rodzinę ${ }^{6}$ tym samym odsuwając w cień podstawowe jej funkcje. Zatem za rodzinę można dziś uznawać związek dwojga ludzi tej samej płci, dając im prawo do wychowania dzieci ${ }^{7}$, oraz nieformalny związek ludzi posiadających dzieci ${ }^{8}$. Jednocześnie pojawiają się głosy postulujące, by za rodziny uznawać grupy ludzi mieszkających wspólnie, niezwiązanych z sobą ani więzią krwi ani małżeńską, czy też ludzi samotnych i ich zwierzęta czy nawet ich przedmioty ${ }^{9}$.

Przyjmując jednak, w opozycji do niektórych współczesnych badaczy ${ }^{10}$, że rodzina jest czymś stałym i jasno określonym, wciąż rozumie się ją jako grupę, w której rodzi się i żyje człowiek, złożoną z najbliższych mu osób ${ }^{11}$. Rodzina nuklearna obejmuje więc dwoje dorosłych ludzi przeciwnej płci z co najmniej jednym dzieckiem ${ }^{12}$.

Tak rozumiana rodzina pozostaje wciąż rodziną najbardziej powszechną ${ }^{13}$, pomimo proponowanych odmiennych jej form. Niniejsze rozważania dotyczą właśnie takiego modelu rodziny ${ }^{14}$. Jaki więc jej wizerunek można zauważyć we współczesnym świecie?

Dom rodzinny często bywa dziś utożsamiany ze światem nudy, trudnych do realizacji zasad, ograniczeń ${ }^{15}$. Często podkreśla się także niebezpieczeństwo występowania w rodzinie sytuacji patologicznych, ukazuje się rodzinę jako miejsce potencjalnego cierpienia (do zainteresowania się świata problemem przemocy rodzinnej przyczynił się w znacznej mierze silny ruch NGO broniący praw dzieci, matek itp.; działalność organizacji pozarządowych jest ceniona i potrzebna

6 T. Szlendak, Socjologia rodziny, Warszawa 2011, s. 106-107.

7 Przykładem może być wynik referendum przeprowadzonego w Irlandii 22.05.2015.

8 W Polsce tylko częściowo przyznaje się konkubinatom prawa przysługujące małżeństwom, zob. J. Grycz, Konkubinat, www.adwokat-rodzinny.pl/13,Konkubinat (29.05.2015).

$9 \quad$ T. Szlendak, Socjologia rodziny..., dz. cyt., s. 107.

10 Tamże.

11 W. Okoń, Słownik pedagogiczny, Warszawa 1992, s. 352.

12 T. Szlendak, Socjologia rodziny..., dz. cyt., s. 96.

13 Główny Urząd Statystyczny, Gospodarstwa domowe i rodziny. Charakterystyka demograficzna. Narodowy Spis Powszechny Ludności i Mieszkań 2011, Warszawa 2014, s. 37.

14 Wybór ten uzasadniają bliżej opisane w kolejnym punkcie cechy szczególne „produktu”.

15 L. Kołakowski, Cywilizacja na ławie oskarżonych, Warszawa1990, s. 140. 
w świecie, który nie jest wolny od przemocy, również w domach rodzinnych) ${ }^{16}$. Zdaniem Jamesa S. Colemana współczesna rodzina „niszczeje, psuje się i jest coraz mniej skuteczna"17.

Takie spojrzenie z pewnością nie jest bezpodstawne. Marek Rembierz zauważa, że istniejąca dziś kulturowa bezdomność wiąże się z promowanym modelem życia, uniemożliwiającym wytworzenie się aksjologicznie rozwiniętej bliskości pomiędzy dzieckiem a rodzicem ${ }^{18}$. Aktualna sytuacja społeczno-ekonomiczna sprawia, że w wielu rodzinach oboje rodzice zajmują się pracą zawodową (z powodu realizacji kariery bądź z konieczności utrzymania rodziny). Mniej jest więc czasu i sił, które przeznaczyć mogą na urozmaicanie życia rodzinnego, czynienie go atrakcyjnym. Wielu rodziców nie wie też, w jaki sposób uczynić z domu miejsce mądrej wolności, co skutkuje zbytnim ograniczaniem lub zupełnym brakiem kontroli i wsparcia. Ponadto charakterystyczne dla współczesności trudności, takie jak brak pracy, zła sytuacja ekonomiczna, nałogi, depresja, agresja itp., powodują, że zdarza się, iż najbliższe osoby stanowią dla współdomowników źródło cierpień psychicznych i fizycznych. Bardzo niepokojące jest to, iż już w podręcznikach dla trzecioklasistów zamieszcza się dziś wskazówki, w jaki sposób dziecko może poinformować świat o tym, że jest ofiarą przemocy. Sytuacja ta powoduje obawy z dwóch powodów. Pierwszy i podstawowy to fakt, że istnieją takie dzieci, które potrzebują tej formy wsparcia i pomocy. Drugi sprowadza się do niepokoju o to, co rozumie się przez stosowane w podręcznikach pojęcie przemocy ${ }^{19}$.

Wydaje się, że opisany powyżej negatywny wizerunek rodziny występuje dziś częściej aniżeli obraz rodziny szczęśliwej. A to właśnie taka rodzina pozostaje marzeniem i celem wielu współczesnych młodych ludzi. Dla wielu ludzi rodzina pozostaje wciąż najważniejszym w życiu celem i wartością.

Przeprowadzone w 2010 roku badania CBOS wykazały, że prawie połowa absolwentów szkół ponadpodstawowych uznała udane życie rodzinne za jeden ze swoich najważniejszych celów ${ }^{20}$. Jeszcze ważniejsze miejsce zajmuje

16 K. Kamińska, Dobro dziecka $w$ dyskursie państwo - rodzina. Inaczej o przemocy domowej, Kraków 2010, s. 76.

17 J. S. Coleman, Racjonalna rekonstrukcja społeczeństwa, „Studia Socjologiczne” 1 (1993), za: W. Segiet, O związku edukacji z rodzina. Społeczne konteksty i jednostkowe biografie, Poznań 2013, s. 56.

${ }_{18}$ M. Rembierz, Dom rodzinny jako „osobliwy szczegót” w świecie kulturowej bezdomności. Refleksje z filozofii człowieka, [w:] Dziecko w świecie rodziny. Szkice o wychowaniu, red. B. Dymara, Kraków 1998, s. 127.

19 Sprawa ta wymaga szczególnej czujności w obliczu treści dokumentów, takich jak Ustawa o ratyfikacji Konwencji Rady Europy o zapobieganiu i zwalczaniu przemocy wobec kobiet i przemocy domowej, zwana potocznie antyprzemocową.

20 R. Boguszewski, K. Kowalczuk, Aspiracje, dążenia i plany życiowe młodzieży, [w:] CBOS, Młodzież 2013, Warszawa 2014, s. 6. 
rodzina w życiu osób, które założyły już swoje rodziny. W przeprowadzonych przeze mnie w 2013 roku badaniach wśród 200 rodziców uczniów szkół podstawowych wszyscy ankietowani przyznali rodzinie pierwsze lub drugie miejsce w swojej hierarchii wartości. Wynik ten był niezależny od kolejności pozostałych wartości.

Oczywiste jest zatem, że rodzina pozostaje niezwykle istotnym elementem życia współczesnych ludzi. Zagrożeniem dla rodziny nie jest więc spadek wartości rodziny w hierarchii ludzkich potrzeb i marzeń. Trudności pojawiają się jednak w określaniu charakteru wskazanego życia rodzinnego oraz w realizacji wzniosłych nieraz ideałów, czego dowodem jest właśnie negatywny obraz rodziny, rosnąca liczba rozwodów ${ }^{21}$ czy wzrastająca liczba dzieci i dorosłych będących ofiarami przemocy domowej (według danych z „Niebieskich Kart” w roku 2014 liczba ofiar przemocy domowej osiągnęła 105332 i była o prawie 20000 wyższa niż w roku poprzednim) ${ }^{22}$.

Warto podkreślić, że tak jak zwiększa się liczba niebezpieczeństw zagrażających ludziom marzącym o szczęśliwej rodzinie, wzrasta również liczba ludzi i instytucji gotowych do niesienia pomocy. Odpowiedzią na alternatywne lub wręcz niszczące rodzinę propozycje są rozwijające się ruchy broniące wartości związanych z życiem rodzinnym.

Podobnie jak dwubiegunowy jest obraz rodziny w społeczeństwie, równie zróżnicowany jest jej wizerunek kreowany przez współczesne środki opiniotwórcze, takie jak media czy instytucje kulturalne. Z jednej strony bowiem widoczny jest tendencja, by osłabiać znaczenie rodziny w jej pierwotnym rozumieniu. Przykładem takich zabiegów może być produkcja licznych filmów i seriali ukazujących życie rodzinne jako pełne intryg i fałszu, pojawianie się w kulturze przekazów środowisk LGBT czy też nagłaśnianie patologicznych zjawisk występujących w rodzinach.

Z drugiej jednak strony, jako że jest to element pożądany i dobrze postrzegany przez społeczeństwo, rodzina bywa często przedstawiana jako wartość wysoka (np. w reklamach ubezpieczeń na życie), wizerunek szczęśliwej rodziny jest też wykorzystywany w reklamach przeróżnych produktów. Ponadto prezentuje się rodzinę jako wymagającą dużego wsparcia, czego przykładem może być chociażby wykorzystywanie programów prorodzinnych w kampaniach politycznych.

Powyższa analiza sytuacji produktu rodzina na rynku współczesnego świata prowadzi do kilku wniosków istotnych dla dalszych rozważań dotyczących konieczności promowania tej marki.

\footnotetext{
21 Rocznik demograficzny GUS, Warszawa 2014, s. 280

22 Dane statystyczne policji, http://statystyka.policja.pl/st/wybrane-statystyki/prze moc-w-rodzinie/50863,Przemoc-w-rodzinie.html (29.05.2015).
} 
WNIOSEK 1: Rodzina narażona jest na oszustwo. Pod jej „markę” podszywają się różne inne „produkty”.

WNIOSEK 2: Rodzina uznawana jest za wysoką wartość przez większość ludzi, niezależnie od światopoglądu.

WNIOSEK 3: Wartość ta narażona jest na brudną reklamę - podkreśla się jej deficyty, niedostatecznie ukazuje blaski.

\section{Rodzina - znaki szczególne}

Po rozpoznaniu aktualnej sytuacji produktu na rynku, należy wskazać charakterystyczne cechy produktu - to, co odróżnia go od innych. Trzeba zatem przyjrzeć się rodzinie pod kątem pełnionych przez nią funkcji, gdyż to właśnie funkcje rodziny sprawiają, że jest ona konkretną, stałą marką, i nie powinno się nadawać tego miana produktom niespełniającym wszystkich charakterystycznych dla niej cech.

Od wieków przypisuje się rodzinie funkcje ${ }^{23}$, dzięki wypełnianiu których jest to grupa cenna zarówno dla jednostki, jak i dla całego społeczeństwa. Pierwszą charakterystyczną cechą rodziny jest jej funkcja reprodukcyjna. Udział w powoływaniu dzieci do życia jest tym, co wyraźnie odróżnia rodzinę od innych form wspólnego życia. Funkcja ta wiąże się ściśle z przypisywaną rodzinie przez socjologów funkcją seksualną. Przyjęcie dzieci niesie ze sobą kolejne zadania dla rodziny, takie jak opieka i socjalizacja, a więc przygotowanie do funkcjonowania w społeczeństwie. Przywilejem i obowiązkiem rodziców jest bowiem wychowanie dzieci, a także zapewnienie im poczucia bezpieczeństwa. W pojęciu tym zawiera się nie tylko zorganizowanie potrzebnych do życia warunków materialnych, ale i stworzenie bezpiecznych warunków dla rozwoju emocjonalnego ${ }^{24}$. Bardzo ważną cechą rodziny jest również to, iż pełni ona funkcję identyfikacyjną. To w rodzinie następuje formowanie się tożsamości dziecka. Często utożsamia się ono z tymi wartościami i postawami, które prezentowane są przez pozostałych członków rodziny. Ponadto należy zaznaczyć, że rodzina ma prawo i odpowiednie możliwości, by postawy te kształtować z poszanowaniem godności dziecka (np. bez uciekania się do technik manipulacyjnych itp.). Maria Ziemska nazywa rodzinę „kolebką osobowości”, jako że jest ona miejscem bliskich interakcji, poprzez które tworzą się struktury osobowości dziecka. Osoby rodziców stanowią dla dziecka wzór postępo-

${ }^{23}$ W oparciu o 10 funkcji rodziny, za: T. Szlendak, Socjologia rodziny..., dz. cyt., s. $116-118$.

24 Tamże, s. 189. 
wania ${ }^{25}$. Rodzina to także przestrzeń, w której ludzie odpoczywają i cieszą się swą obecnością. Odpowiada ona za kontakty dziecka ze społeczeństwem poprzez działania integracyjne, ale także kontrolne. Nieco mniejsze jest współcześnie znaczenie rodziny w nadawaniu swoim członkom statusu społecznego ${ }^{26}$.

Rodzina spełniająca powyższe funkcje, a więc będąca omawianym tutaj produktem oryginalnym, sprawia, że rozwój dziecka przebiega prawidłowo, a w rodzinie dziecko uczy się uczyćc ${ }^{27}$.

Tym, co odróżnia zatem rodzinę od innych form życia wspólnego, jest jej stałość i stabilność. Walorem tego produktu nie jest nowoczesność, a przeciwnie, zakorzenienie w historii, doświadczenie.

Warto jednak zauważyć, iż niektóre funkcje rodziny są dziś przejmowane przez państwo ${ }^{28}$. Na barki społeczeństwa przeniesiona została odpowiedzialność głównie za zadania związane z opiekuńczością i wychowaniem. Coraz częściej też instytucje edukacyjne przejmują prawo do kształtowania postaw i wartości u dzieci, podważając pierwszeństwo rodziny w tym zakresie ${ }^{29}$. Przyczyny tego zjawiska mogą tkwić zarówno w systemie państwowym, jak i w niektórych rodzinach, które z różnych przyczyn same chcą pozbawiać się tego prawa, tej charakterystycznej i niepowtarzalnej cechy, jaką jest udział w kształtowaniu osobowości młodego człowieka. Jako że naturalne pierwszeństwo w wychowaniu dzieci ma rodzina, wszelkie działania $\mathrm{w}$ tym zakresie podejmowane przez inne instytucje dają jedynie namiastką tego efektu, jaki mógłby mieć aktywny udział rodziny.

WNIOSEK 1: Tym, co wyróżnia rodzinę spośród innych grup, jest zdolność rodziców do przekazywania życia, przyjmowania i wychowywania dzieci.

WNIOSEK 2: Niektóre z charakterystycznych dla rodziny zadań są dziś przejmowane przez inne instytucje, co skutkuje osłabieniem jakości ich wypełniania.

\section{Rodzina - przyczyny i cele promocji}

Diagnoza sytuacji danego produktu na rynku oraz wskazanie jego charakterystycznych cech prowadzą do kolejnego kroku w rozważaniu konieczności promocji, który polega na określeniu jej przyczyn i celów. W oparciu o wcześniej-

\footnotetext{
25 M. Ziemska, Rodzina a osobowość, Warszawa 1979, s. 5-6.

26 T. Szlendak, Socjologia rodziny..., dz. cyt., s. 116-118.

27 Tamże, s. 121-124.

28 W. Segiet, O związku edukacji z rodzina..., dz. cyt., s. 56.

29 Przykładem może być aktualna dziś sprawa edukacji seksualnej dzieci w przedszkolach i szkołach.
} 
szą analizę można bowiem odpowiedzieć na pytania, czy i dlaczego współczesna rodzina wymaga reklamy oraz jakim celom reklama ta miałaby służyć.

Za podstawowy motyw promocji rodziny można bez wątpienia uznać wielość i różnorodność pełnionych przez nią, a niezastępowalnych funkcji, które ponadto są wykonywane bezinteresownie, nie otrzymuje się za nie żadnego wynagrodzenia finansowego i nie są podporządkowane interesom żadnej znaczącej grupy społecznej.

Należy również podkreślić, że jak wykazują liczni badacze ${ }^{30}$, zdrowa, silna i stabilna rodzina stanowi alternatywę dla zachowań szkodliwych, często pojawiających się w życiu młodych ludzi. Jest bowiem powszechnie wiadome, że coraz bardziej popularne podejmowanie przez ludzi zachowań ryzykownych wiąże się z nieumiejętnością radzenia sobie z problemami, nudą, brakiem zrozumienia itp. Tymczasem rodzina może właśnie te trudności niwelować, jeśli tylko nie jest miejscem przypadkowym i tymczasowym, ale stanowi środowisko, którego działania są świadome, przemyślane i nastawione na dobro wszystkich swoich członków.

Nie tylko kwestia przekazywania życia, ale również wspieranie zrównoważonego rozwoju wymaga obecności ludzi tworzących prawdziwą wspólnotę opartą na miłości, wzajemnej życzliwości i zrozumieniu, a przede wszystkim na trosce o dobro pozostałych jej członków bardziej niż o dobro własne. Tymczasem instytucje przejmujące niektóre role rodziny nie są w stanie (gdyż jest to naturalnie niemożliwe) stworzyć takich właśnie warunków wychowania młodego człowieka.

Kolejną ważną przesłanką przemawiającą za koniecznością promocji rodziny jest fakt, iż dla wielu ludzi pozostaje ona nadal jedną z najważniejszych wartości i celów w życiu. Skoro zaś członkowie społeczeństwa otwarcie deklarują przywiązanie do niej, należy głos ten nie tylko szanować, ale i wspierać, szczególnie wobec niebezpieczeństwa brudnej kampanii wymierzonej przeciwko tej wspólnej dla zdecydowanej większości ludzi wartości.

Ponadto niezwykle istotna z punktu widzenia współczesności jest kwestia definiowania rodziny. Istnieje groźba „rozmycia” i zagubienia oryginalnego produktu rodzina wśród proponowanych produktów rodzinopodobnych.

Wszystkie wspomniane powyżej tendencje mogą stanowić niebezpieczeństwo dla dalszego rozwoju społeczeństwa, dlatego też uznać należy, że rodzina koniecznie wymaga dziś promocji.

Jakim celom jednak miałaby służyć reklama rodziny? Otóż przede wszystkim zadaniem proponowanej promocji powinno być ukazywanie mocnych stron

30 Między innymi S. Kawula, T. Rostowska, M. Rembierz, J. Brągiel, M. Kalinowski, A. Bandura i wielu innych. 
rodziny, pokazywanie szans, jakie ona stwarza, tak by stanowiło to przeciwwagę dla działań narażających rodzinę na rozmaite niebezpieczeństwa. Trzeba bowiem przywrócić rodzinie dobre imię, które odebrały jej środowiska medialne i kulturowe, by przyciągnąć konsumentów intrygą i sensacją.

Wobec marzenia wielu Polaków o szczęśliwej rodzinie konieczne jest także propagowanie tych postaw i zachowań, które rodzinę umacniają i dają jej większe szanse na trwałość, stabilność, bezpieczeństwo, radość. Działania takie mogą bowiem stanowić wsparcie, wskazówki dla ludzi nieposiadających odpowiednich wzorców, wiedzy czy umiejętności potrzebnych do założenia szczęśliwego ogniska domowego.

\section{Rodzino, jak cię zareklamować?}

Po zdefiniowaniu przyczyn i celów podjęcia działań reklamowych na rzecz rodziny pozostaje jeszcze tylko rozważyć, w jaki sposób zorganizować kampanię reklamową, by była ona jak najbardziej skuteczna.

Jako że odbiorcami promowanego produktu są wszyscy członkowie społeczeństwa, szczególnie zaś młodsza jego część, należy odwołać się do wszelkich występujących dziś rodzajów reklamy. Dotyczy to zarówno korzystania z form środków społecznego przekazu, jak również z reklamy szeptanej.

Z uwagi na znaczny udział młodzieży wśród adresatów promocji rodziny zdecydowanie należy odwołać się w niej do przestrzeni wirtualnej. Najbardziej trafne wydawałoby się w tym zakresie wykorzystanie popularnych portali społecznościowych. Jest to bowiem forma nie tylko najbliższa młodemu pokoleniu, ale również taka, w której (na razie) młodzież nie doszukuje się podstępu. Ponadto funkcjonowanie w tej przestrzeni daje możliwość zaangażowania i bieżącego śledzenia zmian - jest to reklama nieustannie aktywna, dająca możliwość wejścia w interakcję, a także poczucie przynależności do większej grupy odbiorców, z którymi można się utożsamiać.

Równie ważne jest, by pozytywna reklama rodziny pojawiała się wszędzie tam, gdzie mamy do czynienia z ukazywaniem rodziny w złym świetle bądź z próbami podszywania się pod markę „rodzina”. Dlatego również tradycyjne media (prasa, telewizja, radio czy też reklama outdoorowa - $\mathrm{OOH}$ ) powinny prezentować rodzinę, która z radością i oddaniem, bezinteresownie pełni swoje funkcje wobec wszystkich swoich członków.

Najbardziej jednak istotne wydaje się ukazywanie przykładów pozytywnych zachowań i postaw, które służą budowaniu silnej rodziny. Wzorce takie powinny pojawiać się nie tylko w przekazach marketingowych, ale przede wszystkim w życiu codziennym. Żywa reklama stanowi bowiem najbardziej przekonują- 
cą formę oddziaływania na swoich odbiorców. Ponadto dzielenie się pozytywnymi doświadczeniami rodziny (reklama szeptana) jest nieocenioną pomocą w działaniach promocyjnych rodziny.

Nie sposób nie odwołać się i do reklamy ukrytej - swoistego lokowania produktu, które mogłoby się odbywać poprzez wypełnianie wszystkich obszarów funkcjonowania człowieka wartościami prorodzinnymi.

Należałoby zwrócić uwagę na zawartość treściową przekazów zamieszczanych w podręcznikach i głoszonych przez nauczycieli w szkołach. Ponadto warto promować propozycje z zakresu literatury i sztuki, które odwołują się do rodziny w rozumieniu oryginalnym. Wskazane jest także, aby rodzina była wartością autentycznie cenioną przez pracodawców (jak to się dzieje w coraz większej liczbie firm prywatnych, gdzie przedsiębiorcy dostrzegają przełożenie sukcesu w życiu prywatnym na efektywność działań pracownika). Nieocenionym wzmocnieniem reklamowych działań byłoby zwiększenie działań politycznych chroniących tę grupę jako szczególnie uprzywilejowaną - nie z powodu tradycji, konserwatyzmu czy „średniowiecza”, ale z uwagi na wysokie znaczenie i niezastępowalność pełnionych przez nią funkcji nie tylko wobec swoich członków, ale również wobec ogółu społeczeństwa.

Od tego bowiem, jakie rodziny żyją w naszym kraju, zależeć będzie to, jacy są w nim stróże prawa, nauczyciele, naukowcy, sędziowie, politycy czy dziennikarze. Pozostaje więc w naszym wspólnym interesie zadbać o należytą promocję rodziny.

\section{Podsumowanie}

Reasumując, można stwierdzić, iż analiza współczesnej sytuacji rodziny w ujęciu reklamowym ukazuje wciąż znaczące miejsce rodziny wśród wartości ważnych dla współczesnego człowieka.

Jednakże w obliczu specyficznych trudności w funkcjonowaniu rodziny w dzisiejszym świecie rodzina bezpieczna, szczęśliwa, spełniająca stawiane jej oczekiwania pozostaje coraz częściej jedynie w sferze marzeń. Sytuacja ta wiąże się między innymi z nieobiektywnym przedstawianiem rodziny w mediach czy sztuce, brakiem pozytywnych wzorców, problemami na rynku pracy itp.

Można zatem uznać, iż rodzina jest produktem cenionym i pożądanym, z uwagi jednak na zagrożenia, wobec których staje, wymaga swoistego przebudzenia, wyjścia z cienia.

W odniesieniu do przytoczonych we wstępie etapów reklamy można powiedzieć, że w procesie reklamowym rodziny znajdujemy się w obszarze budowania świadomości. Produkt rodzina jest współczesnym znany. Aktualnie konieczne 
jest rozwijanie umiejętności odróżniania go od innych produktów oraz określania cech wyróżniających go, nadających mu szczególną wartość. Przyszłość zaś obejmować będzie nieustanne przypominanie tejże wartości.

Konkludując, rodzina potrzebuje dziś reklamy. Reklamy pozytywnej, skierowanej do wszystkich członków społeczeństwa, szczególnie do młodych, odwołującej się wszelkich form i środków przekazu. Szczególnie zaś wymaga żywej reklamy świadków, którzy swoim życiem i przykładem będą promować trudne, lecz piękne i niezastąpione życie rodzinne.

Aby zaś głos rodziny mógł dotrzeć do wszystkich, konieczne jest zaangażowanie się w tę promocję reprezentantów wszystkich dziedzin życia, którzy świadomi są stawki, o którą toczy się dziś reklamowa wojna.

\section{Bibliografia}

Boguszewski R., Kowalczuk K., Aspiracje, dążenia i plany życiowe młodzieży, [w:] CBOS, Młodzież 2013, Warszawa 2014.

Coleman J. S., Racjonalna rekonstrukcja społeczeństwa, „Studia Socjologiczne” nr 1 (1993).

Główny Urząd Statystyczny, Gospodarstwa domowe i rodziny. Charakterystyka demograficzna. Narodowy Spis Powszechny Ludności i Mieszkań, 2011.

Kamińska K., Dobro dziecka w dyskursie państwo - rodzina. Inaczej o przemocy domowej, Kraków 2010.

Kołakowski L., Cywilizacja na ławie oskarżonych, Warszawa1990.

Okoń W., Stownik pedagogiczny, Warszawa 1992.

Rembierz M., Dom rodzinny jako „osobliwy szczegót” w świecie kulturowej bezdomności. Refleksje z filozofi człowieka, [w:] Dziecko w świecie rodziny. Szkice o wychowaniu, red. B. Dymara, Kraków 1998.

Rocznik demograficzny GUS, Warszawa 2014.

Segiet W., O związu edukacji z rodzina. Społeczne konteksty i jednostkowe biografie, Poznań 2013.

Szlendak T., Socjologia rodziny, Warszawa 2011.

Tkaczyk J., Przepis na reklame, „Pro-Kreacja” nr 3 (2006).

Ziemska M., Rodzina a osobowość, Warszawa 1979.

\section{Źródła internetowe}

Dane statystyczne policji, http://statystyka.policja.pl/st/wybrane-statystyki/przemoc-wrodzinie/50863,Przemoc-w-rodzinie.html (29.05.2015).

Etyka w reklamie, Dokumenty Papieskiej Rady ds. Środków Społecznego Przekazu, http:// iaa.org.pl/o-reklamie/kodeksy/etyka-w-reklamie.html (29.05.2015). 
Grycz J., Konkubinat, http://www.adwokat-rodzinny.pl/13,Konkubinat (29.05.2015).

Liwak A., Reklama - jak to było od początku, http://obserwator.come.uw.edu.pl/Reklamahistoria_-_Agnieszka_Liwak-popr.pdf (29.05.2015). 